\title{
Television Viewing and Consumer Behavior: The Effect of Personality Traits and Demographic Variables on Children's Consumer Socialization.
}

\author{
Dr. Zeenat Ismail \\ Professor - Department of Social Sciences \& Liberal Arts \\ Institute of Business Administration - Karachi \\ Email : zismail@iba.edu.pk \\ Tel: +92(333) 3775545 \\ Fax: +92(21) 38103008 \\ $\&$ \\ Jehangir Kaleem \\ Student of the Institute of Business Administration - Karachi \\ Accepted: May 11, 2013 Published: June 01, 2013 \\ Doi:10.5296/jsr.v4i2.3795 URL: http://dx.doi.org/10.5296/jsr.v4i2.3795
}

\begin{abstract}
The central purpose of this study was to find out the relationship between television viewing habits of children and their consumer behavior, however this study also focuses on possible factors influencing television viewing. A total of 50 questionnaires were distributed to school going children between the ages of 10-12, personality measurements were taken through a semantic test. The aspects of children's consumer socialization included in this study are how much television children watch, what they watch and their purchasing behavior. The children's gender and family income are considered as influences on their television viewing and consumer socialization. Results of the study indicated that family income and personality traits had a significant effect on the Childs consumer socialization; it also identified relationship between other demographic factors and consumer socialization. Shown by a $\mathrm{p}$ value in the chi-square table as $p<0.1$. This research was originally conducted in Malaysia and it will be interesting to see its results in Pakistan, secondly with the growing influence of television viewing in our everyday lives and also the identification of children as a vital part of the consumer population this study carries importance both in the field of psychology and marketing.
\end{abstract}

\section{Keywords:}

Television Viewing, Consumer Behavior, Personality Traits, Age, Family Income, Consumers Socialization

\section{Introduction and background}

Television was invented for the sharing of information and for entertainment. Usually all member of a family watch television, however viewers that are most affected by it are children or 
youth. The importance of children as consumers is now acknowledged. In the US child consumers are not simply a market of 37 million potential young buyers. Globally, this market is exceptional because they are considered to influence three marketplaces. Firstly, young consumers are a primary market, they have their own money to spend on whatever they desire and they may also be asked to do shopping for the family. Secondly, they are a market influencer; they can directly and indirectly influence the shopping habits of others, including their parents. Thirdly, they are a future market who will themselves become consumers of all products and services in years to come. The unique market position of the young consumer has meant that increasingly large budgets are being committed by marketing departments to reach and influence children. However, marketers need to continually rethink their strategies and assumptions, and make cost efficiency their priority. This means that marketers need strategies that target this young sector that are similar to those used for adults.

As the purchasing power of exhibits continuous growth, marketers, manufacturers and advertisers have become increasingly interested in devising effective methods of reaching young people's market. Achieving this aim requires a full understanding of children as consumers: what they believe, what they want and how they behave. McNeil and Ji (1999) determined that television is the most important source of new product information for children and this importance increases significantly as they get older (in comparison with other mass media radio, magazines, newspapers and outdoor ads). They posited that through television advertising children learn about new brands and products, how to use the products and who uses them. Children develop knowledge and opinions about the products and show preferences. As children grow up they get involved in decisions related to purchase of products and services. They may observe, request and select goods with permission while accompanying their parents, shopping as well as making independent visits to shops themselves. Effective decision making requires having in placed the necessary skills to make judgments about different aspects of consumerism. These skills are acquired through a process called consumer socialization. This can be defined as the process by which young people acquire skills, knowledge and attitudes relevant to their functioning as consumers in a marketplace. This process is shaped by many different socio cultural forces however I have only considered two in my research.

\section{Literature review}

Children as consumers: a psychological analysis of the young people's market By Barrie Gunter, Adrian Furnham explains the importance of the children's market and gives us an insight on consumer socialization. According to Nik Rahimah et al (1994), children become consumers through a socialization process. Socialization, as defined by Zigler and Child (1969, cited in Gunter \& Furnham, 1998), is a process by which individuals learn to participate effectively in the social environment. According to Ward (1974, cited in Gunter and Furnham, 1998), the adaptation of this definition to socialization as a consumer was proposed in the mid 1970s, as a vehicle for the study of consumer behavior. Ward defined consumer socialization as the process by which young people acquire skills, knowledge and attitudes relevant to their functioning as consumers in a marketplace. The role of television on consumer demands and habits have also been highlighted in Television Advertising and Consumer Response: Children Buying Behavior By Neeru Kapoor and in the book Perspectives in consumer behavior. The importance of mass media as a socialization agent has received much attention in consumer socialization research (Moore et al 2002, Nik Rahimah et al 1994, Ward 1972 and Caron \& Ward 1975). Moore et al (2002) asserted that market researchers have shown television viewing can play a significant role in the formation of consumer behavior in young people. Nik Rahimah et al (1994) also highlighted the fact the role of television in forming children's consumer behavior is widely documented. Ward (1972) explained the influence of television in children's consumer socialization by looking at children's perceptions, judgment, and understanding of television 
advertising. Ward concluded that the older the child, the better the child's awareness of what advertising is and the greater understanding of the purpose of advertising. Older children also tended to question the credibility of the advertisements. In Ward's study with Caron (1975), he determined the influence of television on children's socialization by looking at their gift ideas. They concluded that older children (ages 10 and above) were more likely to cite television as the source of gift ideas than friends. When considering gender as a factor, no differences were found. In the study made by Nik Rahimah et al (1994), they concluded that of three demographics variables, age, gender and family income, the most influential in explaining differences in socialization is the family income. The result supported the findings made by Caron and Ward (1975). They considered child's age, gender and social class as factors in consumer socialization. Social class was found to be the most important variable in explaining a child's requested gift. In the survey, they concluded that middle-class children (average family income US\$9,000) requested more gifts than upper-class children (average family income US\$14,500). In addition, Goldberg (1990, cited in Nik Rahimah et al 1994) found low-income children tended to purchase a greater number of children's cereals as compared to upper-middle income children. The important of income variable also can be found in explaining the amount of time children spend watching television. Comstock et al (1978, cited in Nik Rahimah et al 1994) found that children with lower income watched more television than middle or upper-middle income children. The study by Nik Rahimah et al (1994) concluded family income is a strong predictor of the time children spend watching television. These findings also determined a link between family income and children's favorite television programmes. Children from families with higher monthly household income tended to like watching cartoons, but they were also interested in other types of programmes such as dramas and thrillers. They also found that both boys and girls like to watch cartoons, but been widely documented. For example, Schramm et al (1961) explained that compared to a group of children with medium and low IQ, children with high IQ tended to watch less television. Also children who found it difficult to make friends watched more television than children with many friends. Hess and Goldman (1962) explained that children who watched a lot of television tended to be lonely, shy, unmotivated and spoilt. Whereas children who watched little television were found to be happier, more flexible in their personalities and more physically active. Coats and Feldman (1995) stated that television is an influential model for children's expression of nonverbal behavior and emotion, such as happiness, sadness, anger, fear and disgust. Even though television has long been recognized as affecting children's understanding of their world, a growing body of research suggests it also affects understanding of their emotions (Coats \& Feldman 1995). In summary, it may be seen that television plays an important role in children's consumer socialization. To further research in this area this study considers family income, gender, personality and television viewing habits as variables in the development of children's consumer socialization.

\section{Research Hypothesis}

There is a significant relationship between family income and children's television viewing habits

There is a significant relationship between personality characteristics and children's purchasing behavior. 
Research Methodology

\section{THE STUdY}

The study is descriptive in nature with survey method used to compute the study as I have studied the effect of different variables on consumer behavior.

\section{MEASUREMENTS}

Consumer Socialization: The aspects of consumer socialization measured were the amount of television children watch, what they watch and their purchasing power.

Demographics (Gender): Male or female

Demographics (Family Income): Above 100, 000 or below 100,000 Rs.

Personality: Personality is 'the distinctive patterns of behavior, including thoughts and emotions that characterize each individual's adaptation to the situations of his or her life' and it will be measured through the using a semantic scale.

\section{SAMPLing DeSign}

Population: Students between the ages of 10-12

Sampling techniques: Judgment sampling was used because of time and money constraints Sampling size: 50 respondents (approx)

Tools for Data collection: self designed questionnaires were observed for underlying pattern

\section{QuantitaTIVE AND QualitaTIVe Research}

Qualitative research (Understanding consumer behavior and reasons behind this behavior) Quantitative Research (investigation of different variables and studying their relationships)

\section{Data Collection}

Primary Data: Primary Data was collected through questionnaires

Secondary Data: Secondary Data sources included research journals, books websites and blogs

\section{STATISTICS APPLIED}

The primary statistical technique applied was the chi-square table Analysis and Results

A total of 50 questionnaires were given out to study the impact of personality traits and demographic factors on children consumer socialization, they results varid but showed a definite 
trend.

Table 1. Sample characteristics

Gender:

Male

Female

Childs age:

10 yrs

11 yrs

12 yrs

Parent's education level

Primary school

Secondary school

Higher education

Monthly household income

Above Rs. 100, 000

Below Rs. 100, 000
29

Frequency

27

23

$46 \%$

5

13

32

$10 \%$

$26 \%$

$64 \%$

3

$6 \%$

4

$8 \%$

21 $\mathbf{5 8 \%}$

$42 \%$ 
Hypothesis testing

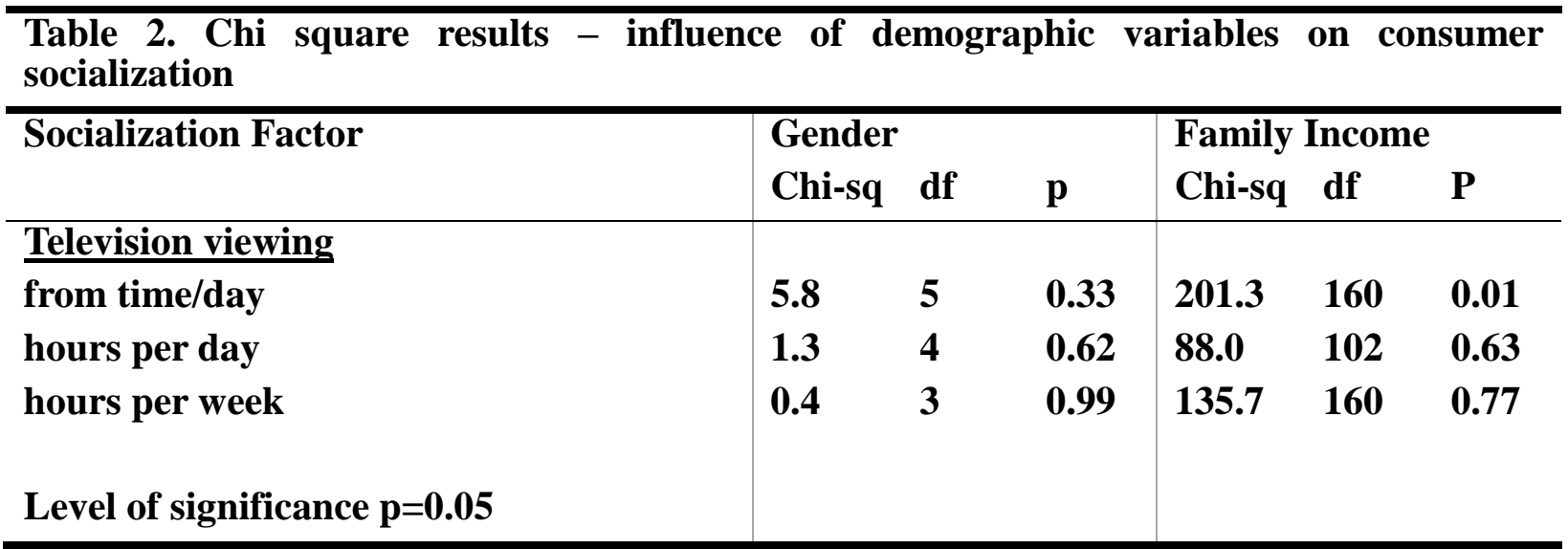

The above table shows the results of the chi square table, showing a significant relationship between times of day television watched and family income as $\mathrm{p}$ value is $<0.05$, proving my first hypothesis. The children with high family income tend to watch more television between 5-8 pm whereas children with low family income tend to watch television between 8-11 pm. The table also indicates that there is no relationship between television viewing and gender as $\mathrm{p}$ value is $>0.05$ and can be concluded that males and females watch the same amount of television.

Table 3. Chi square results -

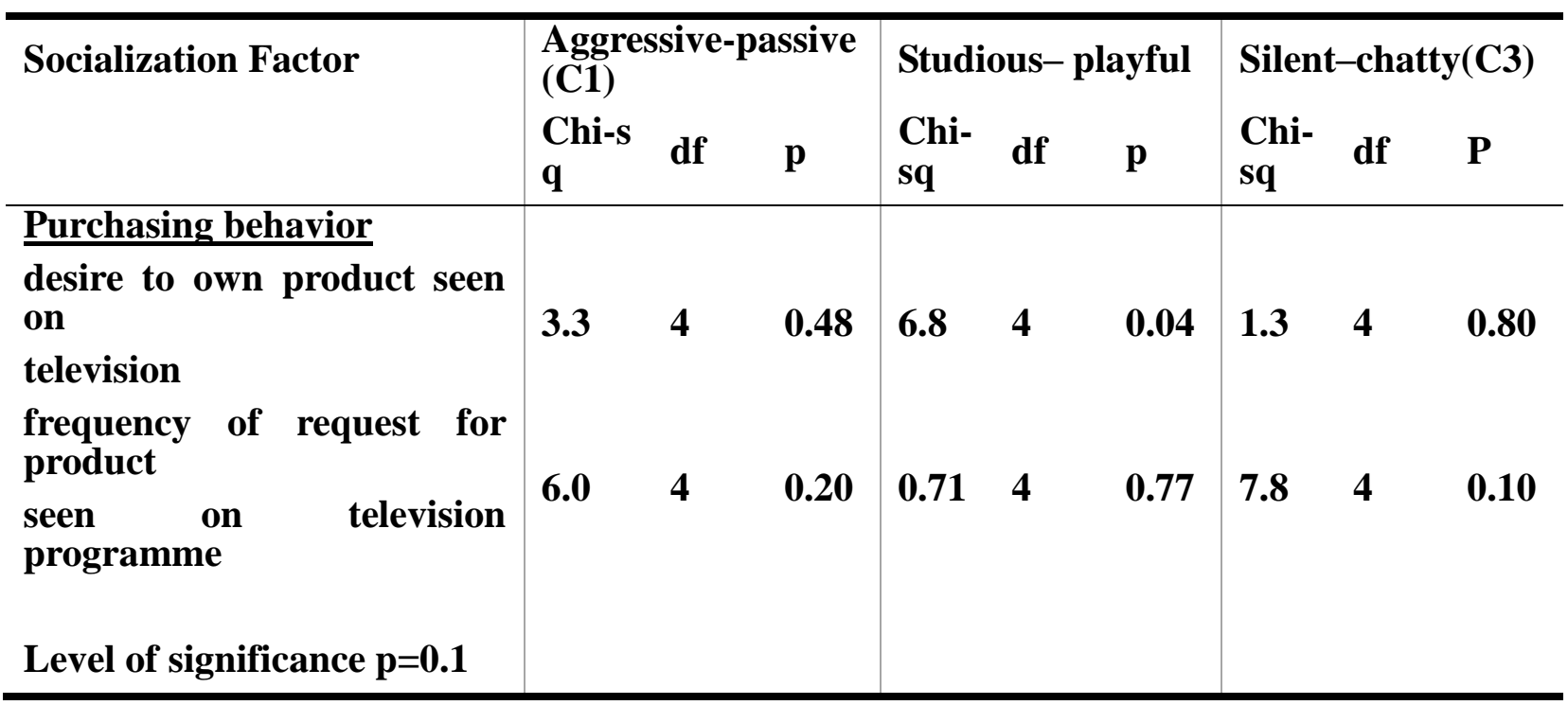

Table 3 shows the relationship between personality traits and purchasing behavior, indicating a significant relationship between silent-chatty personality and frequency of request for product seen on television $(\mathrm{p}=0.10)$, thus proving the second hypothesis. The table also shows a significant relationship between a studious-playful personality and desire to own product seen on television $(\mathrm{p}=0.04)$ 


\section{Discussion and Implication for Future Research}

The influence of television on children's consumer socialization was examined in this study by looking at the influence of demographic variables and personality traits on television viewing and purchase behavior. Of the two demographic variables, the most influential in explaining differences in socialization was the child's family income.

The statistical results with family income functioning as a predictor indicates significant findings in association with the amount of time spent per day watching television, the frequency of requests to purchase a product seen on television. Gender is less influential in explaining the socialization pattern. But gender should not be discounted in future research into children's consumer socialization. Gender is an important variable in explaining the children's consumer socialization as it has a particular influence on the type of programmes preferred by children. Not all of the personality variables had significant effects on children's consumer socialization. Overall, of the six variables that did show a relationship with consumer socialization, The studious-playful personality trait showed significant findings in association with the intention to own a product seen on television Other significant personality traits were rough-gentle, brave-cowardly, silent-chatty, and competitive-tolerant. These traits were found to have significant effects with some of the socialization variables. Although the personality variables alone-friendly, happy-pensive and self-reliant-dependent were less influential they should still be considered by marketers.

Children's personality traits are an important consideration when devising a marketing strategy. Marketers should take these characteristics into account when developing their advertising and research how children with different personalities will perceive their ads. Future research into children's consumer socialization should consider a larger sample and perhaps include different countries. Further demographic variables could include nationality and parental marital status to identify other influences on children's consumer socialization. Another way to increase the value of the survey would be to include details of parents' restrictions on television viewing; the level and effectiveness of such restrictions are now a significant consideration for television advertisers.

\section{Limitations of the Research}

The research only incorporated a small sample using judgment sampling, compromising the validity to some extent.

References

McNeal, J.U. 1992. Kids as consumers: a handbook of marketing to children. New York: Macmillan.

Schiffman, L.G. and Kanuk, L.L. 1997. Consumer behavior. New Jersey: Prentice Hall.

McNeal, J.U. and Ji. M.F. 1999. Chinese children as consumers: an analysis of their new product information sources. Journal of Consumer Marketing

Nik Rahimah, N.Y. et al 1994. Influence of television on children's consumer socialization. Malaysian Management ReviewMoore, J.N et al 2002. Age and consumer socialisation agent influences on adolescents' sexual knowledge, attitudes, and behavior: implications for social 
marketing initiatives and public policy. Journal of Public Policy \& Marketing

Caron, A. and Ward, S. 1975. Gift decisions by kids and parents. Journal of Advertising Research.

Coats E.J. \& Feldman, R.S. 1995. The role of television in the socialisation of nonverbal behavioral skills. Basic and applied social psychology.

Kapoor, A.1994.Television Advertising And Consumer Response: Children Buying Behaviour

Gunter,B.and Furnham,A. Children as consumers: a psychological analysis of the young people's market 